\title{
Preface Monetary stability and economic growth in unstable times
}

By

\section{Robert A. Mundell and Paul J. Zak}

For more than thirty years, the Bologna-Claremont International Monetary Conferences have generated spirited and engaging debates on international monetary policy. They have brought together top experts in international economics to debate and put into context leading issues facing the world economy, recorded for posterity in conference proceedings. This volume falls in the same tradition of its predecessors and reports the proceedings of the fifteenth conference, held in San Miguel de Allende, Mexico, October 1-4, 1999, on the subject "Monetary Stability and Economic Growth in Unstable Times."

The conference had two interesting sequels. One was that nine days after the conference it was announced that Robert Mundell, the conference director, was awarded the Nobel Memorial Prize in Economic Sciences. The other was that nine months after the conference, its major sponsor, Vicente Fox, Governor of the State of Guanajuato, was elected President of Mexico.

The 1999 conference was the first to be held outside the U.S. or Europe, and has resulted in a greater - and welcome - emphasis on developing countries in general and Latin America in particular. There were of course extensive discussions about the "tequila effect" that hit Latin America after the Mexican currency crisis in December, 1994, the "Asian flu" that infected parts of Southeast Asia but left other countries curiously immunized, as well as the Russian bond default in 1998, and the Brazilian devaluation of 1999.

This book does not only report the history of monetary (mis)management, but extracts important policy lessons from this history. Among the issues tackled: How does monetary stability affect economic growth? Which monetary institutions are most and least susceptible to crises? How can countries best achieve monetary stability? When is monetary union desirable? Which anchors for monetary stability are likely to be most effective? How will the advent of the euro affect financial markets and the international monetary 
system? Will the euro become a rival to the dollar? Should the exchange rates among the three largest currency blocs be managed? Is international monetary reform possible and what direction should it take? These subjects provoked lively discussions among the participants. Also recorded are questions and comments from the audience, who attended the conference. When audience members identified themselves their names are included in the text.

Two of the highlights of the conference this year are the Robbins Lecture and the Hinshaw Lecture. The Robbins Lecture was named in memory of Lord (Lionel) Robbins, the important British economist who acted as Director of the Conferences from their inception in 1968 until his death in 1984; the Robbins Lecture this year was delivered by Robert Mundell.

The Hinshaw Lecture, inaugurated at this conference, is named in memory of Randall Hinshaw, the international economist from Claremont Graduate University who managed the entire conference series and edited the proceedings from the beginning in 1968 until his death only last year. The Hinshaw Lecture was delivered by Arnold C. Harberger, Professor Emeritus at the University of California at Los Angeles and former President of the American Economic Association.

We were honored to have Vicente Fox, former Governor of the State of Guanajuato to speak at the adjourning dinner.

It is our pleasure to acknowledge the sponsors of the conference in San Miguel de Allende. They include CILACE, the government of Guanajuato, Ixe, Casa de Bolsa, CEMEX, Cementos de Mexico, Banamex, the Technologico de Monterrey, Claremont Graduate University and the Bologna Center of the Johns Hopkins University. 